\title{
PENGARUH FAKTOR-FAKTOR PRODUKSI PADA USAHATANI LADA DI DESA SWATANI KECAMATAN RILAU ALE KABUPATEN BULUKUMBA
}

\author{
Andi Annisa Sulolipu \\ STKIP Pembangunan Indonesia Makassar \\ Email : Annisafachri.aas@gmail.com
}

\begin{abstract}
ABSTRAK
Penelitian ini bertujuan untuk mengetahui pengaruh faktor produksi berupa luas lahan, pupuk NPK, pestisida dan tenaga kerja baik secara simultan maupun secara parsial dapat mendorong peningkatan hasil produksi lada di Desa Swatani Kecamatan Rilau Ale Kabupaten Bulukumba.Populasi dalam penelitian ini sebanyak 152 orang dengan sampel 30 orang yang ditarik dengan menggunakan teknik Simple Random sampling.Teknik pengumpulan data yang digunakan adalah observasi, wawancara, dokumentasi dan angket. Analisis data yang digunakan adalah analisis cobb douglas.Hasil penelitian menunjukkan bahwa faktor produksi berupa luas lahan, pupuk NPK, pestisida dan tenaga kerja secara simultan berpengaruh positif dan signifikan terhadap produksi lada di Desa Swatani Kecamatan Rilau Ale Kabupaten Bulukumba, sedangkan secara parsial luas lahan (X1) berpengaruh positif dan signifikan terhadap produksi lada, pupuk NPK (X2) berpengaruh negatif dan tidak signifikan terhadap produksi lada, pestisida (X3) berpengaruh negatif dan tidak signifikan terhadap produksi lada dan tenaga kerja (X4) berpengaruh negatif dan signifikan terhadap produksi lada di Desa Swatani Kecamatan Rilau Ale Kabupaten Bulukumba.
\end{abstract}

Kata Kunci: Faktor Produksi, Usaha Tani Lada

\section{PENDAHULUAN}

Salah satu sektor yang sangat penting dalam proses pembangunan nasional adalah pembangunan sektor pertanian pada umumnya dan khususnya sub sektor perkebunan yang tetap diharapkan sebagai mesin penggerak perekonomian nasional. Oleh sebab itu, arah kebijakan pembangunan pertanian perlu ditekankan pada visi dengan menetapkan sektor pertanian sebagai sektor andalan dengan misi mewujudkan pertanian modern, tangguh dan efesien yang dipertajam pada upaya peningkatan pendapatan petani dan masyarakat pedesaan diseluruh pelosok tanah air.

Suatu kenyataan yang tak dapat dipungkiri bahwa struktur ekonomi Sulawesi Selatan masih didominasi oleh sektor pertanian. Dari kenyataan inilah sehingga sampai saat ini propinsi Sulawesi Selatan masih mengandalkan hasil atau komoditi yang berasal dari sektor pertanian sebagai komoditi yang diekspor keluar negeri untuk memperoleh devisa yang dapat digunakan dalam membangun daerah ini. Di samping itu sektor pertanian dikatakan dapat menyediakan lapangan kerja bagi para angkatan kerja yang ada di daerah ini yang belum memperoleh pekerjaan lain terutama bagi mereka yang hanya mempunyai tingkat pendidikan rendah dan 
96|Ad'ministrare, Vol. 3 No. 2, 2016

tidak mempunyai keahlian khusus atau skill yang dapat dipakai untuk bekerja di sektor lainnya. Hal ini disebabkan karena dalam melakukan usaha di sektor pertanian tidak terlalu dibutuhkan keahlian khusus dan tingkat pendidikan yang cukup tinggi dalam artian bahwa sektor pertanian dapat dikelola dengan menggunakan cara tradisonal.

Namun cara mengelolah usahatani yang masih bersifat tradisional tersebut tidak dapat memberikan hasil produktif yang optimal. Sebagaimana yang diharapkan agar output yang diperoleh dari usahatani yang dikelolah itu senantiasa akan meningkat yang selanjutnya akan meningkatkan pada pendapatan mereka. Mengingat sebagian besar penduduk indonesia hidup didaerah pedesaan yang bermata pencarian di bidang pertanian dan sub sektor perkebunan, maka sewajarnyalah jika pembangunan itu lebih banyak diarahkan untuk memperbaiki kehidupan petani di daerah pedesaan. Oleh karena itu, petani merupakan golongan yang berpendapatan rendah sebagaimana telah disebutkan diatas, maka keadaan hidupnya sangat ditentukan oleh hasil pertaniannya. Tingkat pendapatan petani sangat tergantung pada jumlah produksi, harga jual, dan biaya-biaya yang dikeluarkan petani dalam suatu usahatani. Ini berarti bahwa perhatian pemerintah terhadap sektor pertanian merupakan usaha untuk memperbaiki kehidupan sebagaian besar penduduk indonesia yang tergolong miskin.

Di Kabupaten Bulukumba, Khususnya di Kecamatan Rilau Ale Desa Swatani merupakan salah satu produksi lada yang sangan potensial baik dari keadaan alam, iklim, maupun dari segi lahan yang sudah dimanfaatkan dengan baik oleh petani. Sumber daya manusia di daerah ini sangat besar jumlahnya dan sangat potensial dalam pengembangan pertanian, khususnya di sektor pertanian lada. Dengan demikian adanya daya dukung alam maka prospek pembudidayaan lada di Desa Swatani Kec. Rilau Ale cukup baik. Sehubungan dengan hal tersebut maka pihak pemerintah bersama masyarakat terus berupaya membudidayakan lada, pihak pemerintah selama ini berupaya memberikan penyuluhan kepada para petani lada sehingga para petani diharapkan dapat mengelolah pertanian lada secara profersional.

Lada merupakan salah satu bumbu dapur yang cukup menjanjikan dalam meningkatkan kesejahteraan masyarakat di Kabupaten Bulukumba khususnya di Kecamatan Rialu Ale di Desa Swatani, maka dalam pembudidayaannya memerlukan perhatian khusus dari kalangan petani, sehingga lada tersebut memberikan kontribusi yang positif dalam meningkatkan kesejahteraan para petani lada. Walaupun dengan adanya dukungan alam dan luas lahan yang memadai akan tetapi tanpa dikelolah dengan profesional, mustahil aktivitas petani lada tersebut dapat memberikan nilai tambah dalam meningkatkan pendapatan atau kesejahteraannya.

Demikian pula halnya dengan faktor modal yang dimiliki dalam mengelolah lahan pertanian lada,dalam proses pengelolaannya memerlukan tenaga kerja yang memadai sehingga selama ini cenderung pihak petani mengupah tenaga kerja yang sifatnya tidak tetap. Sehubungan dengan hal tersebut dengan daya dukungan lahan, tenaga kerja dan modal yang dimiliki petani lada diharapkan mampu meningkatkan produksinya. Hal ini dapat dilihat pada tabel 1 . 
Andi Annisa Sulolipu, Pengaruh Faktor-Faktor Produksi Pada Usahatani Lada di Desa Swatani Kecamatan

Rilau Ale Kabupaten Bulukumba $\mid 97$

Tabel 1.Luas Lahan dan Produksi Lada Di Kabupaten Bulukumba Tahun 2008-2011

\begin{tabular}{lcccccccc}
\hline \multicolumn{1}{c}{ Kecamatan } & \multicolumn{3}{c}{ Luas Lahan (ha) } & \multicolumn{5}{c}{ Hasil Produksi (ton) } \\
& 2008 & 2009 & 2010 & 2011 & 2008 & 2009 & 2010 & 2011 \\
\hline \hline Gantarang & 335 & 335 & 335 & 335 & 163 & 165 & 154,9 & 153 \\
Ujung Bulu & - & - & - & - & - & - & - & - \\
Ujung Loe & 163 & 163 & 163 & 163 & 90 & 90 & 84,8 & 82,3 \\
Bontobahari & 2,5 & 2,5 & 2,5 & 2,5 & 1 & 2,7 & 2,2 & 0,15 \\
Bantotiro & 116 & 116 & 116 & 116 & 65 & 75 & 64,8 & 1,69 \\
Herlang & - & - & - & - & - & - & - & \\
Kajang & 219 & 219 & 219 & 219 & 119 & 0,2 & 168,8 & 167 \\
Bulukumpa & 605 & 605 & 605 & 605 & 305 & 305 & 286,9 & 292 \\
Rilau Ale & 858 & 858 & 858 & 858 & 564 & 564 & 552 & 552 \\
Kindang & 202,4 & 202,4 & 202 & 202 & 97 & 97 & 94,7 & 96 \\
\hline
\end{tabular}

Sumber: BPS, Kab. Bulukumba Tahun 2012

Dari Tabel 1.1 diatas, dapat dilihat data Luas lahan dan, hasil produksi di Kabupaten Bulukumba pada empat tahun terakhir mengalami fluktuasi.Dimana pada data diatas juga menunjukkan dari sepuluh kecamatan di Kabupaten Bulukumba di Kecamatan Rilau Ale merupakan penghasil produksi lada terbesar dengan hasil produksi pada tahun 2011 sebesar 552 ton. Kemudian di susul oleh Kecamatan Bulukumpa dengan hasil produksi sebesar 292 ton.

\section{KAJIAN TEORI}

\section{Konsep Usahatani}

Menurut Soekartawi (2006:1) mengemukakan bahwa "Ilmu Usahatani dapat diartikan sebagai ilmu yang mempelajari bagaimana seseorang mengalokasikan sumberdaya yang ada secara efektif dan efisien untuk tujuan memperoleh keuntungan yang tinggi pada waktu tertentu". Dikatakan efektif bila petani atau produsen dapat mengalokasikan sumberdaya yang mereka miliki (yang dikuasai) sebaik-baiknya, dan dikatakan efisien bila pemanfaatan sumberdaya tersebut menghasilkan keluaran (output) yang melebihi masukan (input).

Usahatani pada skala usaha yang luas umumnya bermodal besar, berteknologi tinggi, manajemennya modern, lebih bersifat komersial, dan sebaliknya usahatani skala kecil umumnya bermodal pas-pasan, teknologinya tradisional, lebih bersifat usahatani sederhana dan sifat usahanya subsisten, serta lebih bersifat untuk memenuhi kebutuhan konsumsi sendiri dalam kehidupan sehari-hari. 
98|Ad'ministrare, Vol. 3 No. 2, 2016

\section{Konsep Budidaya Tanaman Lada}

Tanaman lada termasuk tanaman rempah yang banyak dikembangkan di Indonesia. Tanaman lada juga merupakan salah satu sumber pendapatan masyarakat Indonesia. Akan tetapi dalam pengelolaan tanaman lada juga diperlukan tata cara penanaman yang benar agar kualitas dari lada itu sendiri juga baik.

\section{Konsep Fungsi Produksi dan Faktor Produksi}

\section{Fungsi Produksi}

Menurut Sese dan Rajab (2000), Rosyidi (2005) dan Mubyarto (2007) mengemukakan bahwa fungsi poduksi adalah "hubungan fisik antara input-input sumber daya perusahaan dan output barang dan jasa yang dihasilkannya per unit waktu". Dalam perumusan ekonomi, fungsi produksi memperlihatkan hubungan teknis antara bermacam-macam input dan output. Fungsi produksi menyatakan kepada kita bahwa terdapat berbagai pilihan diantara bermacam-macam kombinasi faktor produksi (input) yang tidak terhitung banyaknya, guna menghasilkan sejumlah output tertentu. Dari uraian diatas dapatlah ditarik suatu kesimpulan bahwa produksi yang dihasilkan selalu tergantung atau merupakan fungsi dari faktor produksi.

Hubungan antar input dan output atau faktor produksi dan output atau jumlah produksi disebut sebagai fungsi produksi. Berdasarkan pola hubungan antara input dan output produksi tersebut, maka menurut Ilyas (2009: 19) ditentukan atas tiga zona produksi yaitu (a) zona 1 yaitu daerah irrasional I, (b) zona II yaitu daerah rasional dan (c) zona III yaitu daerah irrasional.

Fungsi produksi dari semua produsen tunduk kepada suatu hukum yang tersebut dengan the law of deminishing teturn atau biasa disebut the law of deminishing marginal physical product. Menurut hukum ini, apabila satu macam faktor produksi di tambahkan penggunaannya, sedangkan faktor - faktor produksi lain tetap (ceteris paribus) maka tambahan hasil produksi yang dihasilkan mula-mula naik, tetapi suatu saat turun bila faktor produksi ditambah. Untuk mengetahui hubungan antara input dan output dapat dinyatakan dengan persamaan matematik sebagai berikut:

Dimana :

$$
\mathrm{Q}=\mathrm{F}\left(\mathrm{X}_{1}, \mathrm{X}_{2}, \mathrm{X}_{3} \ldots \mathrm{X}_{\mathrm{n}}\right) \ldots \ldots .(\mathrm{II} .1)
$$

$\mathrm{Q}=$ Tingkat produksi (output)

$\mathrm{X}_{1}, \mathrm{X}_{2}, \mathrm{X}_{3}, \ldots \ldots . \mathrm{X}_{4}=$ input yang digunakan dalan menghasilkan sejumlah $\mathrm{Q}$ tertentu (Boediono 1984).

Fungsi produksi dapat diubah dalan beberapa bentuk atau model matematis. Salah satu bentuk fungsi sederhana yang sering digunakan dalam menganalisis produksi pertanian adalah fungsi produksi cobb-Douglas. Tipe fungsi Cobb Douglas merupakan fungsi logaritmik yang dapat dinyatakan dalam persamaan matematik dengan formulasi sabagai berikut: 


$$
\mathrm{Y}=X_{1}^{a 1} \mathrm{a}_{0}, X_{2}^{a 2}, \ldots \ldots . . . X_{n}^{a n}
$$

Adapun penaksirannya model ini dapat ditransfer ke dalam logaritma natural linear, dengan demikian formulasinya berubah menjadi :

$$
\operatorname{LnY}=\operatorname{Ina} a_{0}+a_{1} \operatorname{Inx} x_{1}+a_{2} \operatorname{In} x_{2}+a_{n} \operatorname{Inx}
$$
Dimana :

$$
\begin{aligned}
& \mathrm{Y}=\text { output } \\
& \mathrm{X}_{1}=\text { input }(\mathrm{I}=1,2 \ldots \ldots \ldots \ldots \ldots . . \mathrm{n}) \\
& \mathrm{Ln} \mathrm{a}_{0}=\text { intercept } \\
& \text { ai } \quad=\text { parameter fungsi, juga merupakan elastisitas faktor produksi }(1,2, \ldots \ldots . \mathrm{n})
\end{aligned}
$$

Ada beberapa keuntungan dalam penggunaan fungsi produksi dengan menggunakan model Cobb-Douglas yakni:

a. Hasil pendugaan akan menghasilkan koefisien regresi sekaligus elastisitas

b. Jumlah elastisitas sekaligus merupakan tingkat skala usaha (Return to Scale)

Bila $\sum$ bi $>1$ menunjukkan skala usaha yang meningkatkan, bila $\sum \mathrm{bi}=1$ menunjukkan skala usaha yang konstan dan bila $\sum$ bi $<1$ menunjukkan skala usaha yang menurun.

\section{Faktor Produksi}

Istilah faktor produksi sering pula di sebut dengan "korbanan produksi", karena faktor produksi "dikorbankan" untuk menghasilkan faktor produksi. dalam bahasa inggris, faktor produksi ini disebut dengan "input". Macam faktor produksi atau input ini, berikut jumlah dan kualitasnya perlu diketahui oleh seorang produsen. Oleh karena itu, untuk menghasilkan suatu produk, maka diperlukan pengetahuan hubungan antara faktor produksi (input) dan produksi (output).

Hubungan antara input dan output disebut dengan faktor produski "faktor relationship" (FR). Dalam rumus matematisnya, FR dituliskan dengan rumus:

$$
\mathrm{Y}=\mathrm{f}(\mathrm{X} 1, \mathrm{X} 2, \mathrm{X} 3 \ldots \mathrm{Xn}) \text {.(II. 4) }
$$

Dimana:

$\mathrm{Y}=$ produk atau variabel yang dipengaruhi oleh faktor produksi $\mathrm{X}$

$\mathrm{X}=$ faktor produksi atau variabel yang mempengaruhi $\mathrm{Y}$.

Produksi tertentu tidak akan dapat dilakukan kalau tidak ada bahan-bahan yang memungkinkan dilakukannya produksi itu sendiri. Untuk bisa melakukan produksi, dibutuhkan unsur-unsur yang menopang usaha penciptaan nilai atau usaha memperbesar nilai barang yang kemudian disebut faktor-faktor produksi. Maka faktor-faktor tersebut yang dimaksud ialah a) Tanah (land), atau Sumber Daya Alam (Natural resources), b)Tenaga Kerja (Labor) atau Sumber Daya Manusia (Human Resources), c)Modal, d)Kecakapan Tata Laksana 
100|Ad'ministrare, Vol. 3 No. 2, 2016

\section{Faktor Produksi dalam pertanian}

Secara umum ada beberapa faktor yang dapat menentukan produk Lada dalam proses pertanian, ialah:

\section{a. Luas Lahan}

Luas lahan pertanian merupakan suatu yang sangat penting dalam proses produksi ataupun usahatani dan usaha pertanian. Luas lahan pertanian akan mempengaruhi skala dan pada akhirnya mempengaruhi efisien atau tidaknya suatu usaha pertanian, tetapi kita berasumsi bahwa semakin luas lahan maka semakin banyak hasil produksi. tetapi seringkali dijumpai bahwa semakin luasnya lahan yang dipakai semakin tidak efisien usaha tersebut. Ini dasarkan pada pemikiran bahwa luasnya lahan usahatani mengakibatkan upaya untuk melakukan tindakan yang mengarah pada segi efisiensi akan berkurang karena terbatasnya modal, lemahnya pengawasan terhadap faktor-faktor produksi dan terbatasnya tenaga kerja.

\section{b. Tenaga kerja}

Menurut Daniel (2002: 86) mengemukakan bahwa "Tenaga kerja adalah suatu alat kekuatan fisik dan otak manusia, yang tidak dapat dipisahkan dari manusia dan ditujukan pada usaha produksi".

\section{c. Pupuk}

Pupuk merupakan bahan yang mengandung unsur hara yang diperlukan tanaman untuk pertumbuhannya atau menyuburkan tanah. Seperti halnya manusia, selain mengkonsumsi nutrisi makanan pokok dibutuhkan pula konsumsi nutrisi vitamin sebagai tambahan makanan pokok tanamanpun demikian, selain air sebagai konsumsi pokoknya, pupukpun sangat dibutuhkan dalam pertumbuhan yang optimal.

\section{d. Pestisida}

Pestisida adalah bahan yang digunakan untuk mengendalikan, menolak, memikat, atau membasmi organisme pengganggu (hamaatau penyakit). Namun ini berasal dari pest "hama" yang diberi akhiran cide "pembasmi". Sasarannya bermacam-macam, seperti serangga, tikus, gulma, burung, mamalia, ikan atau mikroba yang dianggap mengganggu.

\section{Hipotesis}

Berdasarkan permasalahan yang dikemukakan maka, diajukan hipotesis sebagai berikut: 
1. Faktor produksi seperti Luas lahan, pupuk, pestisida dan tenaga kerja secara simultan maupun secara parsial berpengaruh signifikan terhadap produksi Tanaman Lada Di Desa Swatani Kecamatan Rilau Ale Kabupaten Bulukumba

2. Skala usaha berada pada tahap decreasing rate.

\section{METODE PENELITIAN}

Penelitian ini mengkaji variabel atau memusatkan perhatian pada analisis usahatani lada di Desa Suwatani Kecamatan Rilau Ale Kabupaten Bulukumba. Populasi dalam penelitian ini sebanyak 152 orang dengan sampel 30 orang yang ditarik dengan menggunakan teknik Simple Random sampling.Teknik pengumpulan data yang digunakan adalah observasi, wawancara, dokumentasi dan angket.

Berdasarkan pada rumusan masalah dan hipotesis yang telah diajukan diatas maka untuk mengetahui hubungan antar input yang digunakan dan output yang dihasilkan. Dalam rumus matematis fungsi produksi dapat dituliskan dengan:

$$
\mathrm{Y}=\mathrm{f}\left(\mathrm{X}_{1}, \mathrm{X}_{2}, \mathrm{X}_{3}, \mathrm{X}_{4} \ldots \ldots \ldots \ldots \mathrm{X}_{\mathrm{n}}\right)
$$

Dimana:

$\mathrm{Y}=$ Produksi atau variabel yang dipengaruhi oleh faktor produksi $\mathrm{X}$

$\mathrm{X}=$ faktor produksi atau variabel yang mempengaruhi $\mathrm{Y}$

$\mathrm{X}_{1}=$ Luas lahan

$\mathrm{X}_{2}=$ Pupuk NPK

$\mathrm{X}_{3}=$ Pestisida

$\mathrm{X}_{4}=$ Tenaga Kerja

Fungsi produksi yang lebih sering digunakan oleh para peneliti adalah fungsi produksi degan model analisis Cobb-douglas (Tiro: 2002:260) dengan persamaan sebagai berikut:

$$
\mathrm{Y}=\beta_{0} \mathrm{X}_{1}{ }^{\beta 1} \mathrm{X}_{2}{ }^{\beta 2} \mathrm{X}_{3}{ }^{\beta 3} \mathrm{X}_{4}{ }^{\beta 4} \ldots . . \mathrm{X}_{\mathrm{k}}^{\beta \mathrm{k}}
$$

Dimana:

$\mathrm{Y}=$ Jumlah produksi (output)

$\beta_{0}=$ Intercept

$\beta_{1}, \beta_{2}, \beta_{3}, \beta 4=$ Koefesien regresi

$\mathrm{X}_{1}=$ Luas lahan

$\mathrm{X}_{2}=$ Pupuk NPK

$\mathrm{X}_{3}=$ Pestisida

$\mathrm{X}_{4}=$ Tenaga Kerja

$€=$ Kesalahan Acak (In)

Untuk memudahkan mengistemasi nilai-nilai $\beta_{1}, \beta_{2}, \beta_{3}, \beta_{4}$, maka di tarik logaritma natural

Ln $Y=\operatorname{In} \beta_{0}+\beta_{1} \operatorname{In} X_{1}+\beta_{2} \operatorname{In} X_{2}+\beta_{3} \operatorname{In} X_{3}+\beta_{4} \operatorname{In} X_{4} €$ 
$102 \mid$ Ad'ministrare, Vol. 3 No. 2, 2016

Dimana:

Ln Y= logaritma natural produksi Lada

$\operatorname{Ln} \beta_{0} \quad=$ Intercept

Ln $\mathrm{X}_{1} \quad$ =logaritma natural Luas lahan

Ln $\mathrm{X}_{2}=$ logaritma natural Pupuk NPK

Ln $\mathrm{X}_{3}=$ logaritma natural Pestisida

Ln $\mathrm{X}_{4} \quad=$ logaritma natural Tenaga Kerja

$\beta 1, \beta 2, \beta 3, \beta 4=$ Koefesien regresi

$€=$ Kesalahan Acak

Jika notasi In $Y$, In $\beta_{0}$, In $X_{1}$, In $X_{2}$, In $X_{3}$, In $X_{4}$ masing-masing diganti dengan persamaan $Y^{*}, \beta_{0}^{*}, X_{1}, X_{2}, X_{3}, X_{4}$, maka persamaan dari transformasi kedaam logaritma natural diatas menjadi:

$$
\mathrm{Y}^{*}=\beta_{0} *, \beta_{1} \mathrm{X}_{1}^{*}, \beta_{2} \mathrm{X}_{2}^{*}, \beta_{3} \mathrm{X}_{3}^{*}, \beta_{4} \mathrm{X}_{4} *
$$

Melalui uji f maka tabel analisis variansi (ANAVAR). Pengujian ini bertujuan untuk mempelajari apakah fakor produksi diatas secara bersama-sama (simultan) mempunyai pengaruh yang bermakna terhadap tingkat produksi. Hipotesis yang diperhatikan adalah:

$\mathrm{H}_{0}: \beta 1: \beta 2: \beta 3: \beta 4=0$ melawan

$\mathrm{H} 1: \beta \mathrm{i} \neq 0$ dimana $\mathrm{i}(1,2,3,4)$

salah satu dari beta tidak sama dengan nol.

Melalui uji t maka pengujian ini bertujuan untuk mempelajari apakah tahap produksi diatas secara persial mempunyai pengaruh yang bermakna terhadap tingkat produksi, hipotesis statistik yang diperhatikan pada produksi ini adalah Y. Untuk mengetahui apakah skala produksi berada pada tahap increasing, decreasing, dan constant rate mak digunakan konsep Return to scale (RTS) yaitu konsep yang ingin menjelaskan seberapa besar output berubah bila jumlah faktor produksi dilipat gandakan. Yang dapat digambarkan dalam keadaan sebagai berikut:

a. Skala hasil menaik (increasing return to scale) bila Ep $>1$ ini berarti produksi berada pada tahap 1 atau increasing rate (tahap irrasional 1)

b. Skala hasil menurun (decreasing return to scale) bila $1>\mathrm{Ep}>0$ maka produksi berada pada tahap II atau decreasing rate (yahap irrasional)

c. Skala hasil konstan (constant return to scale) bila Ep < 0, maka produksi berada pada tahap III atau negatif decreasing rate )tahap irrasional II).

\section{HASIL DAN PEMBAHASAN}

\section{Hasil Penelitian}

Usahatani lada di Desa Swatani Kec.Rilau Ale Kab.Bulukumba merupakan sumber pendapatan utama bagi petani.Hal ini terbukti dari hasil produksi yang dihasilkan pada satu kali musim panen setiap responden atau petani bervariasi.Hal ini disebabkan karena adanya beberapa 
perbedaan baik itu luas lahan, pupuk, pestisida, tenaga kerja dan sebagainya.Berikut distribusi responden menurut jumlah produksi yang dihasilkan oleh petani merica dalam 1 tahun atau 1 kali panen.

Tabel 2 Distribusi Responden Menurut Jumlah Tenaga Kerja di Desa Swatani Kecamatan Rilau Ale Kabupaten Bulukumba, Tahun 2015.

\begin{tabular}{rlcc}
\hline No. & Produksi $(\mathrm{Kg})$ & Jumlah Responden & Persentase $(\%)$ \\
\hline 1 & $2600-3800$ & 8 & 26,67 \\
2 & $3900-5100$ & 6 & 20 \\
3 & $5200-6400$ & 6 & 20 \\
4 & $6500-7700$ & 3 & 10 \\
5 & $7800-9000$ & 7 & 23,33 \\
6 & $9100-10300$ & 0 & 0 \\
\hline & Jumlah & 30 & 100 \\
\hline
\end{tabular}

Sumber: Data primer setelah diolah, Tahun 2015

Berdasarkan tabel 2, menunjukkan bahwa 8 responden atau 26,67\% yang memiliki hasil roduksi lada sebesar $2600-3800 \mathrm{~kg}, 6$ responden atau $20 \%$ yang memiliki hasil produksi lada sebesar $3900-5100 \mathrm{~kg}, 6$ responden atau $20 \%$ yang memiliki hasil produksi lada sebesar 5200 $-6400 \mathrm{~kg}, 3$ responden atau 10\% yang memiliki hasil produksi lada sebesar $6500-7700 \mathrm{~kg}$ dan 7 responden atau $23,33 \%$ yang memiliki hasil produksi lada sebesar $7800-10300 \mathrm{~kg}$. Hal ini menunjukkan bahwa jumlah produksi lada yang dihasilkan setiap kali panen cukup besar yang berarti bahwa lada sangat menguntungkan jika diproduksi, mengingat harga lada juga cukup tinggi.

\section{Pembahasan}

Pada penelitian ini terdapat 2 faktor produksi yang mempengaruhi secara langsung terhadap produksi lada di Desa Swatani Kecamatan Rilau Ale Kabupaten Bulukumba yaitu luas lahan dan tenaga kerja. Disamping itu ada juga yang mempengaruhi secara tidak langsung yaitu pupuk NPK dan pestisida.

Tabel 3 Hasil Analisis faktor-faktor produksi di Desa Swatani

Kecamatan Rilau Ale Kabupaten Bulukumba, Tahun 2015

\begin{tabular}{|l|c|r|r|r|}
\hline \multicolumn{1}{|c|}{ Variabel Independen } & TH & \multicolumn{1}{c|}{ B } & \multicolumn{1}{c|}{ t-hit } & \multicolumn{1}{c|}{ Sign } \\
\hline Luas Lahan & + & 1.341 & 8.332 & $.000^{* *}$ \\
Pupuk NPK & + & -.178 & -1.456 & $.158^{*}$ \\
Pestisida & + & .037 & .424 & $.675^{*}$ \\
Tenaga Kerja & + & -.233 & -.209 & $.009^{* *}$ \\
\hline
\end{tabular}


104|Ad'ministrare, Vol. 3 No. 2, 2016

\begin{tabular}{|l|r|}
\cline { 2 - 2 } Konstant & 2.993 \\
F Hitung & 64.406 \\
Sign F & $.000^{* *}$ \\
R2 & .912 \\
N & 30 \\
\hline
\end{tabular}

Sumber: Data primer setelah diolah, Tahun 2015

Keterangan :

TH : Tanda harapan

** : Taraf Signifikansi dan kesalahan 0,05 (5\%) atau tingkat kepercayaaan 95\%

* : Tidak Signifikan

Taraf signifikan merupakan taraf kepercayaan. Dalam penelitian ini menggunakan taraf signifikan 0,01 (1\%) artinya taraf kepercayaan atau taraf kebenaran sebesar 99 persen dan tingkat kesalahan 1 persen dan taraf signifikan 0,05 (5\%) artinya taraf kepercayaan atau taraf kebenarannya adalah 95 persen dan tingkat kesalahan 5 persen. Jika memperhatikan kembali bentuk persamaan setelah menarik logaritma natural dari persamaan regresi Cobb Douglass yaitu:

Ln $Y=\operatorname{In} \beta_{0}+\beta_{1} \operatorname{In} X_{1}+\beta_{2} \operatorname{In} X_{2}+\beta_{3} \operatorname{In} X_{3}+\beta_{4} \operatorname{In} X_{4} €$

Hasil olah data melaui computer spss 17 , berdasarakan tabel diatas menunjukkan bahwa nilai $\beta_{0}, \beta_{1}, \beta_{2}, \beta_{3}$ dan $\beta_{4}$ adalah sebagai berikut:

$\operatorname{Ln} \mathrm{Y}=2,993 \ln \beta 0+1,341 \ln \beta_{1}-0,178 \ln \beta_{2}+0,037 \ln \beta_{3}-0.233$ $\ln \beta_{4}$.

Keterangan:

$\ln \beta_{0} \quad=$ Produksi Lada

$\ln \beta_{1} \quad=$ Luas Lahan

$\ln \beta_{2} \quad=$ Pupuk NPK

$\ln \beta_{3} \quad=$ Pestisida

$\ln \beta_{4} \quad=$ Tenaga Kerja

Untuk mengetahui keberartian koefisien regresi maka dilakukan uji $\mathrm{F}$, adapun uji $\mathrm{F}$ yang dimaksud dapat dilihat pada tabel 1.4 menunjukkan bahwa nilai $\mathrm{F}$ hitung sebesar 64,406 > F tabel sebesar 2,975 dengan signifikan 0,000 jauh lebih kecil dari taraf signifikan yang digunakan dalam penelitian ini yaitu $0,05 \%$. Dengan demikian dapat disimpulkan bahwa pengujian hipotesis tersebut menolak $\mathrm{H}_{0}$ dan menerima $\mathrm{H}_{1}$. Hal ini menunjukkan bahwa luas lahan, pupuk NPK, pestisida dan tenaga kerja secara simultan mempunyai pengaruh positif dan signifikan terhadap Produksi Lada di Desa Swatani Kecamatan Rilau Ale Kabupaten Bulukumba.

Tabel 3 dapat dilihat koefisien determinasi $\left(\mathrm{R}^{2}\right)$ sebesar 0,928 , berarti variansi faktor produksi luas lahan, pupuk NPK, pestisida dan tenaga kerja memberi kontribusi terhadap produksi lada di Desa Swatani Kecamatan Rilau Ale Kabupaten Bulukumba. Untuk mengetahui faktor produksi mana saja yang mempunyai pengaruh yang bermakna terhadap hasil produksi Lada di Desa Swatani Kecamatan Rilau Ale Kabupaten Bulukumba dilakukan uji t. Berikut 
variabel yang memiliki pengaruh terhadap produksi Lada di Desa Swatani Kecamatan Rilau Ale Kabupaten Bulukumba

\section{Luas Lahan}

Tabel 3 menunjukkan bahwa dimana luas lahan berpengaruh positif dan signifikan terhadap produksi lada . Hal ini dapat dilihat dari nilai thitung 8,332 > t tabel 2,060 maka $\mathrm{H}_{0}$ menolak dan $\mathrm{H}_{1}$ menerima dengan tingkat signifikan 0,000 jauh lebih kecil dari taraf signifikan yaitu $0,05 \%$. Selanjutnya koefesien regresi sebesar 1,341 yang berarti jika penambahan luas lahan $1 \%$ akan meningkatkan 1,341 produksi lada.

\section{a. Pupuk NPK}

Pada tabel 3 menunjukkan bahwa pupuk NPK berpengaruh negatif dan tidak signifikan terhadap hasil produksi Lada. Hal ini terlihat dari t hitung $-1,456<\mathrm{t}$ tabel 2,060 maka $\mathrm{H}_{1}$ di tolak dan $\mathrm{H}_{0}$ diterima dengan taraf signifikan yaitu 0,158 jauh lebih besar dari taraf signifikan yang digunakan yaitu $0,05 \%$. Selanjutnya koefesien regresi sebesar $-0,178$ yang berarti jika penambahan pupuk $1 \%$ akan menurunkan 0,178 produksi lada.

\section{b. Pestisida}

Pada tabel 3 menunjukkan bahwa pestisida berpengaruh positif dan tidak signifikan terhadap hasil produksi Lada. Hal ini terlihat dari t hitung $0,024<\mathrm{t}$ tabel 2,060 maka $\mathrm{H}_{1}$ di tolak dan $\mathrm{H}_{0}$ diterima dengan taraf signifikan yaitu 0,675 jauh lebih besar dari taraf signifikan yang digunakan yaitu $0,05 \%$ Selanjutnya koefesien regresi sebesar 0,037 yang berarti jika penambahan pestisida $1 \%$ akan meningkat 0,037 produksi lada.

\section{Tenaga Kerja}

Tabel 3 menunjukkan bahwa dimana tenaga kerja berpengaruh negatif dan signifikan terhadap produksi lada . Hal ini dapat dilihat dari nilai t hitung $-1,913<\mathrm{t}$ tabel 2,060 maka $\mathrm{H}_{0}$ diterima dan $\mathrm{H}_{1}$ ditolak dengan tingkat signifikan 0,009 jauh lebih kecil dari taraf signifikan yaitu $0,05 \%$. Selanjutnya koefesien regresi sebesar $-0,233$ yang berarti jika penambahan tenaga kerja $1 \%$ akan meningkatkan 0,233 produksi lada.

Selanjutnya untuk mengetahui skala usahatani lada dapat dihitung elastis produksinya (ep). Berdasarkan perhitungan elastisitas produksi maka dapat diketahui dengan cara menjumlahkan nilai koefisien regresi atau parameter elastisitasnya seperti yang terdapat pada tabel 4.12 di atas, yaitu sebagai berikut:

$$
\begin{aligned}
\text { Ep } \quad & \beta 1+\beta 2+\beta 3+\beta 4 \\
& =1,341+(-0,178)+0,037+(-0,233) \\
= & 0,97
\end{aligned}
$$


106|Ad'ministrare, Vol. 3 No. 2, 2016

Jadi nilai elastisitas produksi lada adalah kurang dari 1 (Ep < 1) sehingga dapat disimpulkan bahwa pemanfaatan faktor-faktor produksi yang terdiri dari luas lahan, pupuk NPK, pestisida dan tenaga kerja berada pada tahap II atau decreasing rate. Hal ini berarti bahwa setiap penambahan input sebesar $1 \%$ akan terjadi penurunan output paling sedikit $1 \%$.

\section{SIMPULAN}

Berdasarkan hasil penelitian mengenai analisis pemanfaatan faktor produksi dan pendapatan petani lada di Desa Swatani Kecamatan Rilau Ale Kabupaten Bulukumba.

1. Dalam pengujian variabel bebas melalui uji $f$, menunjukkan bahwa faktor produksi lada berupa luas lahan, pupuk NPK, pestisida dan tenaga kerja secara simultan berpengaruh positif dan signifikan terhadap produksi lada di Desa Swatani Kecamatan Rilau Ale Kabupaten Bulukumba.

2. Dalam pengujian vaiabel bebas melalui uji t, menunjukkn bahwa luas lahansecara parsial berpengaruh positif dan signifikan terhadap produksi lada, sedangkan Pupuk NPK dan pestisida tidak berpengaruh negatif dan signifikan terhadap produksi lada dan tenaga kerja berpengaruh negatif dan signifikan terhadap produksi lada di Desa Swatani Kecamatan Rilau Ale Kabupaten Bulukumba.

3. Penggunaan faktor-faktor produksi berupa luas lahan, pupuk NPK, pestisida dan tenaga kerja sudah optimal. Hal ini berarti bahwa kegiatan produksi yang dilakukan oleh petani lada dalam menggunakan ketiga faktor produksi berada pada tahap decreasing rate, sehingga petani tidak perlu menambah faktor produksi karena akan mengalami penurunan faktor produksi.

\section{DAFTAR PUSTAKA}

Daniel, Moeher. 2002. Pengantar Ekonomi pertanian. Jakarta: Bumi Aksara

Mubyarto. 2007. Pengantar ekonomi Pertanian. Jakarta. LP3ES

Rosyidi. 2005. Pengantar Teori Ekonomi. Jakarta. PT. Raja Grafindo Persada

Sese, Abd. Rajab. 2000. Pengantar Ilmu Ekonomi. CV. Jaya Riska Abadi. Makassar

Soekartawi, 2004. Teori Ekonomi Produksi. Raja Grafindo Perkasa. Jakarta

Soekartawi. 2006. Analisis Usahatanbi. U-I Press 